\title{
Determination of Reservoir Play Fairway of the Lower Acacus Formation in the Ghadames Basin, NW Libya
}

\author{
Omar B. Elfigih \\ Associate Professor, Petroleum Geologist, Department of Earth Sciences, Faculty of Science, \\ University of Benghazi, Benghazi-Libya
}

\begin{abstract}
The investigated well data sets have revealed that the Lower Acacus Formation in Ghadames Basin can be defined by two deltaic complexes correspond to two distinct prograded clastic wedges, that appear to exhibit significant differences in net sandstone thickness, lateral extension and lithofacies development. The play fairway of the Lower Acacus sandstones is considered to be wide enough and corresponding to a sequence of inter bedded fluvial-deltaic sandstones, marine sandstones and shale. To date, drilling activities targeting these reservoir sandstones have been concentrated in the central and northern part of the fairway. Production from these sandstones has been impressive. Average daily flow rate have increased from less than 300 BOPD and 0.1 MMCFGPD to more than 1000 BOPD and 5 MMCFGPD. Analyses of well test performance on the level of Lower Acacus sandstone reservoirs suggest an ultimate oil reserves for the entire fairway in the Ghadames Basin.
\end{abstract}

Keywords: Play, Fairway, Lower Acacus reservoirs, Ghadames Basin.

\section{INTRODUCTION}

The study area is called Ghadames (Hamada) Basin located in the northwestern part of Libya and occupied an area of $150,000 \mathrm{~km}^{2}$. Structurally, it is bounded from the north by Nefusa Uplift, from the south by Gargaf Arch, from the east by Tripoli Soda Arch and from the west by the partial extension of Tihemboka Uplift (Fig.1).

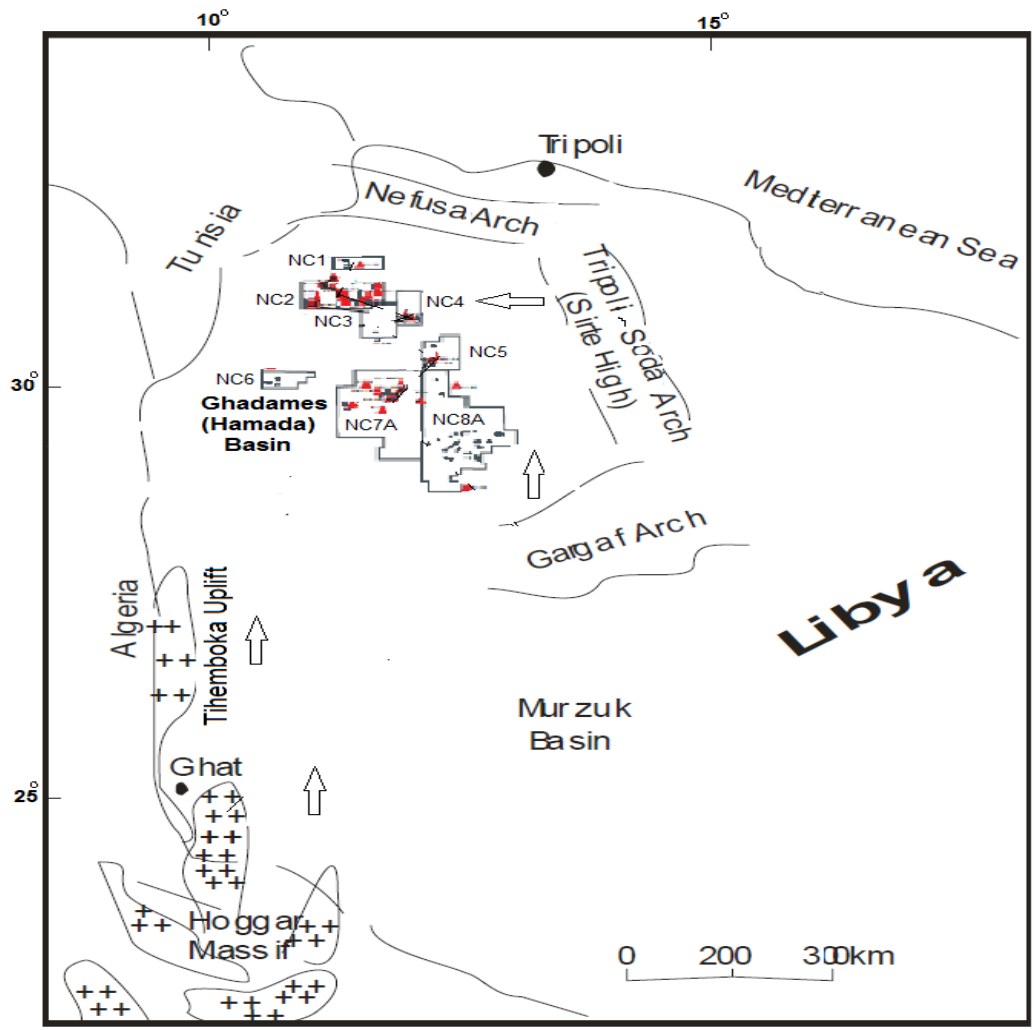

Figure1. Location map and the main structural elements of Ghadames Basin, NW Libya. (Arrows are indicting directions of sediments transportation from source areas, modified after [9]) 
In the Ghadames (Hamada) Basin, several new and ongoing plays have exhibited considerable success, beginning in the 1980'sowing in the large part to the discovery of the multi-reservoirs in the Paleozoic-Mesozoic sequence. Among these sandstone reservoirs are the Lower Acacus sandstones (U. Silurian). In particular, the Lower Acacus sandstones are unique in terms of being most prolific and may represent one of the most prospective horizons in the Ghadames (Hamada) Basin. For these reasons this paper will be dealing with the possible definition, determination and spatial extension of the reservoirs play fairway of the Lower Acacus Formation.

\subsection{Previous Work}

A number of regional studies investigated potential play types and addressed new regional evaluations of the Ghadames (Hamada) Basin. Hammuda (1978) [1], summarized the results of a geological study conducted as part of an evaluation for recoverable reserve estimates for NOC. He concluded that AlHamada Al Hamra (Ghadames Basin) area had more traps than had been discovered to that time. Echikh and Sulieman (1982) [2], completed a geological study and petroleum evaluation of the Ghadames Basin for NOC, no new original work was contributed. Shah et al. (1988) [3], studied geological factors controlling the oil and gas deposits of the Ghadames (Hamada) Basin, and made recommendations for their future exploration. Santa Maria (1991) [4], completed a regional study on the Ghadames (Hamada) Basin. The main purpose of this study was to evaluate the hydrocarbon potential on the light of characteristic sedimentary cycles for the stratigraphic sequence in the Ghadames Basin. Elfigih (1991) [5], studied the reservoir characteristics of the Lower Acacus Formation in NC2 concession and furnished the idea of possible two deltaic pulses that may be contributed to the formation of the sandstones of Lower Acacus Formation. Cridland (1991) [6], completed a seismic stratigraphic evaluation of $\mathrm{NC} 2$ concession in which he integrated his seismic interpretation with existing studies, and referred to possible play types of Lower Acacus sandstone reservoirs in his study. Technica Exploitation Group (1995) [7], initiated an exploitation study for AGOCO regarding hydrocarbon pools of Lower Acacus sandstones in selected wells in the west of NC2 concession, and recommended these sandstones for their good reservoir quality. Elfigih (2000) [8], has completed a study leading to $\mathrm{PhD}$ degree entitled regional diagenesis and its relation to facies change in the Upper Silurian, Lower Acacus Formation, Hamada (Ghadames) Basin, NW Libya. He furnished the basis for approaches to the analysis of regional diagenesis and for establishment of parameters for basin-wide 3D geological model to achieve regional understanding of diagenetic change and for realistic reservoir representation and prediction. Elfigih (2010) [9], has published a paper entitled: regional aspects of the Lower Acacus sandstone play, Ghadames Basin, NW Libya, in which he interpreted fluvio-deltaic pulses in the Lower Acacus sandstones and said may be used to furnish the playground for the application of sequence stratigraphic analysis for the first time in the Ghadames Basin. Elfigih (2010) [10], has published a paper entitled: The prospectivity of the Devonian reservoirs in the concession NC8A, Hamada (Ghadames) Basin, NW Libya (a case study), in which he concluded that, the Devonian sandstones in concession NC8A could be regarded as of shallow targets and their prospectivity is largely dependent on vertical and lateral facies change.

\subsection{Purpose of the Study}

By using core data, well logs, isopach pattern maps and through detailed north-south cross section of the Lower Acacus Formation, the outcome of this study will provide a better understanding of depositional environment and distribution of deltaic facies complexes and will contribute to a better definition and prediction of the fairway of the Lower Acacus reservoirs in the Ghadames basin.

\section{Methodology}

To achieve the objectives of this study, methods employed were:

Analysis, correlation, and calibration of conventional wireline logs, and cores to provide information for interpretation of the stratigraphic framework, units, and depositional environments of the Lower Acacus Formation. Stratigraphic cross-sections of wireline logs and stratigraphic/structural subsurface mapping of Lower Acacus Formation were used to reconstruct the configuration of strata; they form the basis for determination of play fairway in the study area.

\section{STratigraphy}

Extensive wireline data sets are loaded for each well and core description data results are incorporated. Based on these data, well correlation panels are built through N-S and NE-NWN regional cross sections (Figs.2 and 3). In both cross sections, Stacked fluvial-deltaic deposits are included within a foreland sequence and alternating with marginal(prodeltaic) to marine deposits from south to north and 
Determination of Reservoir Play Fairway of the Lower Acacus Formation in the Ghadames Basin, NW Libya

from northeast to northwest-north directions, sourced possibly from Cambrian-PreCambrian orogenic belt (high areas) to the south and to the northeast (Fig.1). Laterally from south to north (Fig.2) and from northeast to northwest-north (Fig.3); the Lower Acacus sandstones comprise proximal foreland fluvial channel deposits include conglomerates and sandstones (Af1-Af9 units). To the central part (in the vicinity of concessions NC2, NC3, NC4 and NC5) of the Ghadames Basin, Silurian seaway was acted as site for deltaic sandstones (A1-A14 units) accumulation which are changing N-NW direction to more marginal siltstone, shale and reworked marine sandstones (Am units). Vertically, underlying the Lower Acacus sandstones is the marine, thick Tanezzuft shale, where the overlaying deposits is the middle Acacus shale. Previous studies of the Lower Acacus interval have tended to focus either on its northern (NC2 concession) or southern part (NC7A and NC8A concessions). For this reason, the present paper has focused on the regional well data available throughout the Ghadames Basin. Meanwhile, to show that the Lower Acacus sandstones are typified by having complex architectures that involves facies changes, overlapping or truncation of individual facies especially northward.

$\mathrm{N}$

S

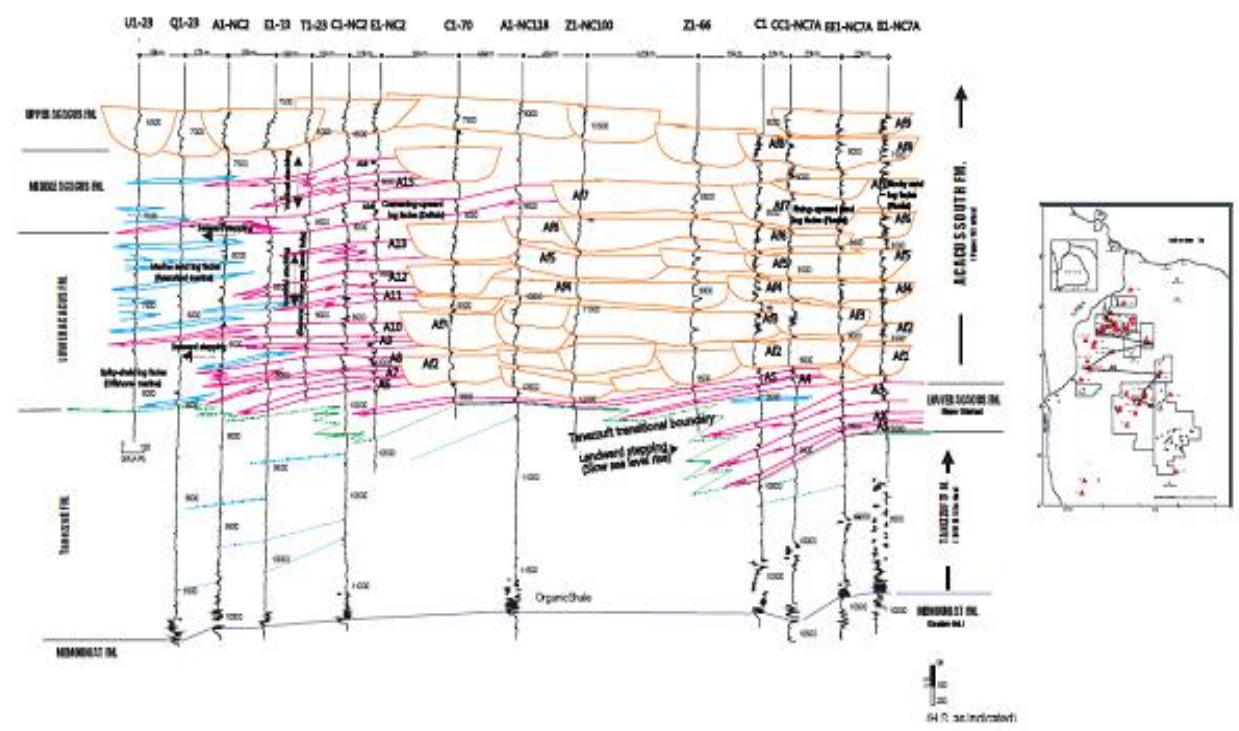

Figure2. North-South well-logs regional cross section illustrating the typical Gamma Ray signature associated with the depositional facies that make-up the possible prograded sequence of the southern delta of the Lower Acacus Formation, Ghadames Basin, NW Libya (after [9]).

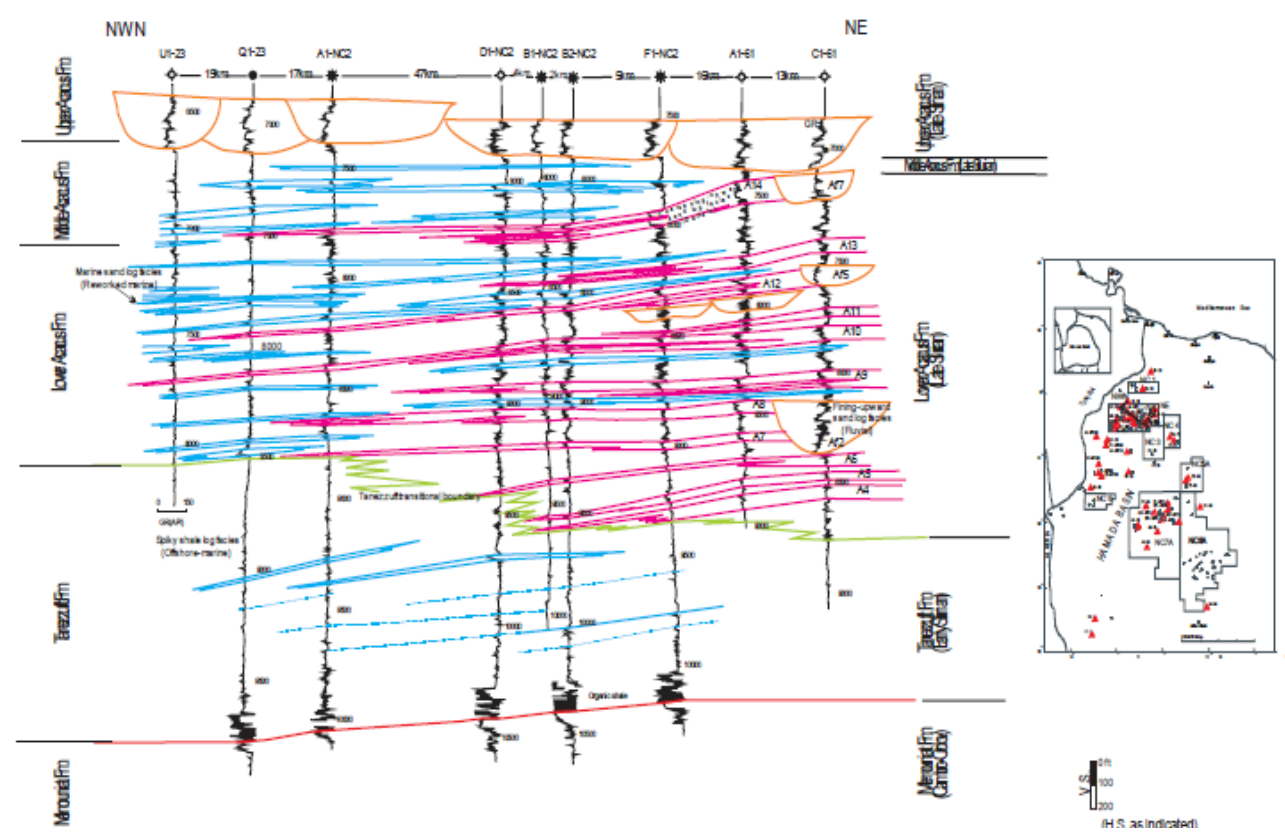

Figure3. Northeast-northwest-north stratigraphic cross section in the northern flank of the Ghadames Basin showing possible prograded eastern delta (after [9 ]). 


\section{LiTHOFACIES ANALYSIS}

According to Elfigih (1991 and 2000), the Lower Acacus sandstones are divided into about 14 sandstone units, where regional integration of wireline-logs and core description permits analysis of some specific units (A8, A10, A12, A14, Af3 and Am) as they appear the most thicker, of great extension, and most prolific units throughout the basin. The description of these units and their representative lithofacies is as following:

\subsection{Unit A8 (Parallel-Cross Laminated Sandstone Lithofacies)}

This unit have been examined in core \#4, in well C1-NC2 at an interval of 9702'-9732', (Fig. 4), and was described as fine-medium grained, subangular to rounded with parallel and cross lamination Sandstone with alternating shale lamination, of proximal delta front origin.

\subsection{Unit A10 (Wavy-Rippled Sandstone Lithofacies)}

This unit have been examined in core \#2, in well B1-NC2 at an interval of 8637'-8650', (Fig. 5), and was described as light grey-light green, fine-medium grained, friable at some places, subangular to rounded, well sorted sandstone, with mud clasts, wavy-rippled lamination at top, calcareous cement, shaly at the base of proximal delta front origin.

\subsection{Unit A12 (Cross Laminated, Carbonaceous Sandstone Lithofacies)}

This unit have been examined in core \#1, in well C1-70 at an interval of 9710'-9730', (Fig. 6), and was described as grey, grayish white, fine grained, subangular-subrounded, moderately sorted sandstone, occasionally with carbonaceous materials, cross laminated, rip-up clasts, calcareous, with oil stain, of proximal delta front origin.

\subsection{Unit A14 (Parallel To Indistinctive Laminated Sandstone Lithofacies)}

This unit have been examined in core \#1\&2, in well E1-NC2 at intervals of 9105'-9126'\& 9126'9146', (Fig.7), and was described as '"grey, occasionally tan, medium grained, subangular to rounded, moderately sorted sandstone, with mud clasts, parallel lamination with oil stain at top, indistinctive lamination and some burrows at bottom, of proximal delta front origin.

\subsection{Unit Af3 (Trough Cross Laminated To Ripple Laminated Sandstone Lithofacies)}

This unit have been examined in core \#8, in well Z1-66 at an interval 9110'-9160', (Fig.8), and was described as light grey, whitish cream, medium grained, Sandstone with trough cross lamination at base, non calcareous, getting finer grained at top, rippled at places, channel fill. Some silty shale at the most top, light grey, sticky, gummy, horizontal lamination, rootlets, of overbank deposits. Also this unit Af3 was described as massive, iron oxides-rich sandstone of fluvial fill origin in well C1-61 in core \#3 at interval 7507'-7555' (Fig. 9).

\subsection{Unit Am (Glauconitic, Rippled Sandstone Lithofacies)}

This unit have been examined in core \#1\&2, in well Q1-23 at intervals of 7440'-7470' and 7470'7485', (Fig.10), and was described as whitish grey, fine grained, subangular-subrounded, moderately sorted sandstone, micaceous in parts, glauconitic, rippled, calcareous, reworked marine sandstone origin.

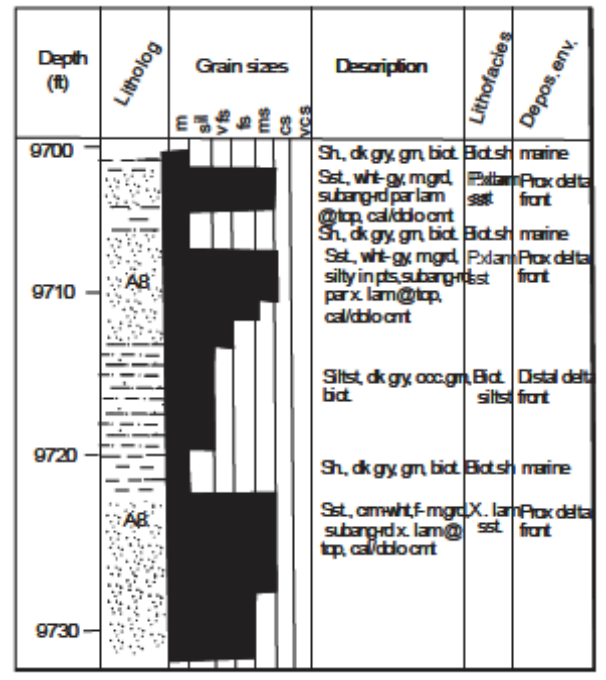

Figure4. Unit A8, C\#4 of Lower Acacus Fm., in wellC1-NC2

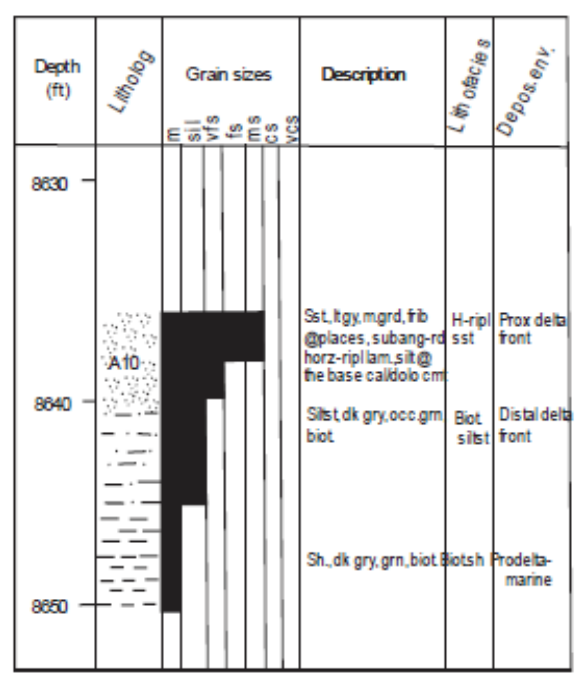

Figure5. Unit A10, C\#2 of Lower Acacus Fm., in well B1-NC2, 
Determination of Reservoir Play Fairway of the Lower Acacus Formation in the Ghadames Basin, NW Libya

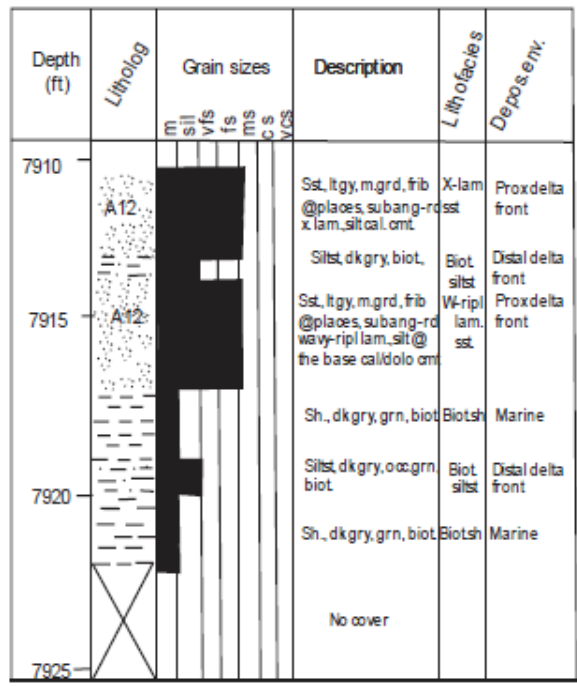

Figure6. Unit A12, C\#1 of Lower Acacus Fm., in well C1-70

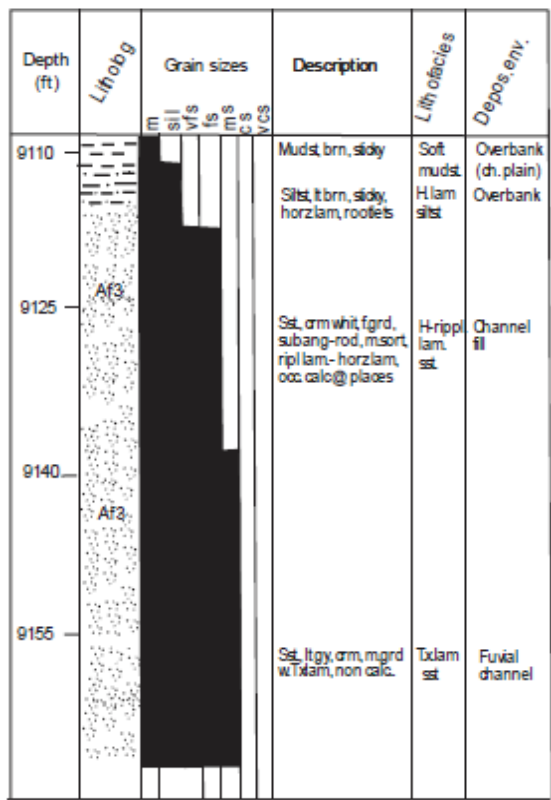

Figure8. Unit Af3, C\#8 of Lower Acacus Fm., in well Z1-66

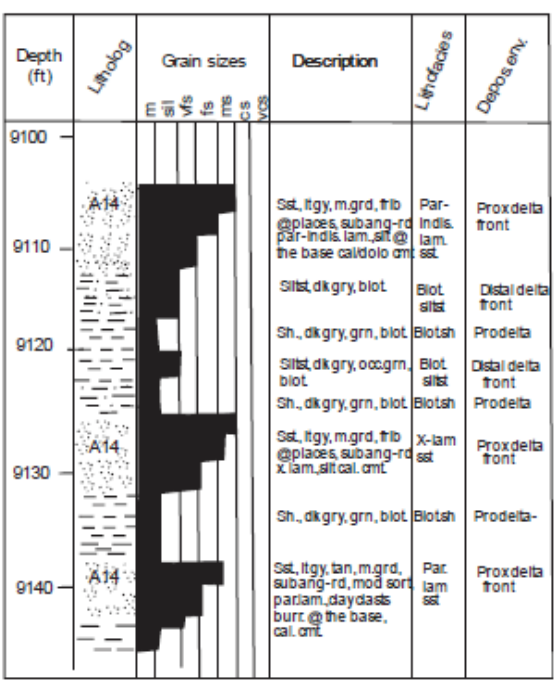

Figure 7. Unit A14, C\#1\&2 of Lower Acacus Fm., in well E1-NC2

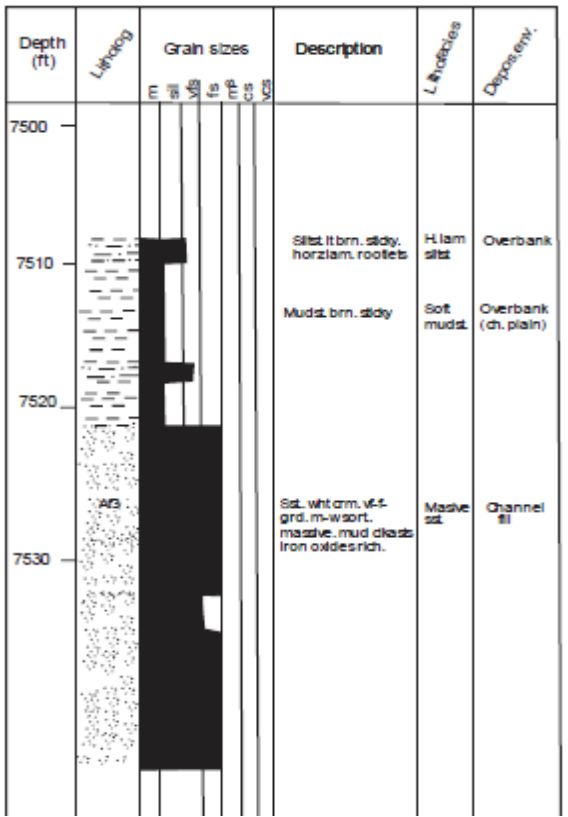

Figure9. Unit Af3, C\#3 of Lower Acacus Fm., in well C1-61

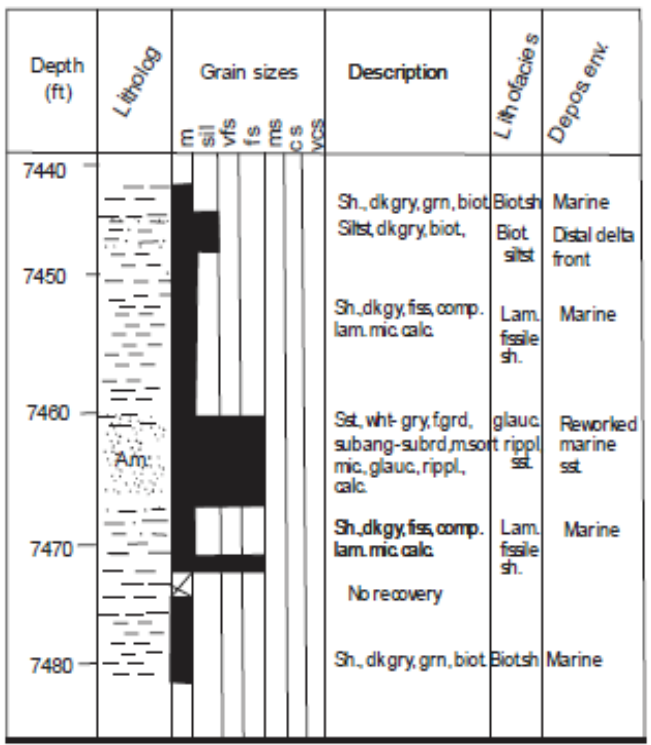

Figure10. Unit Am, C\#1\&2 of Lower Acacus Fm., in well Q1-23 


\section{SAndstone Patterns}

Regional net sandstone isopach patterns of the Lower Acacus Formation are showing in (Fig.11). The mapped sandstone units are recorded 75API or less on GR-Log. Isopach trends from thick to thin area are largely oriented to N-NW and E-W, to show a regional lobate morphology fashion gets more linear to the south as may infer from channel like contours configuration which reflect the accumulation of the fluvial channel deposits where the isopach maxima $220 \mathrm{ft}$ and extend at least $250 \mathrm{~km}$ from south to north, compared with the eastern part (in the vicinity of NC2, NC3 \&NC4) of about 130ft and extends about $100 \mathrm{~km}$ to the west reflect a westerly shift to northern shoreline orientation. However, individual sand beds are observed to split or merge over short and long distances with thicker channel sands exhibiting good continuity between wells especially in the southern part of the basin.

A fairly abrupt boundary is evident in the vicinity of (NC8A concession) extends to SW of well L-1, which have been interpreted as marking the southern limit of the Lower Acacus Formation as this formation have been truncated by erosion along this high relief area.

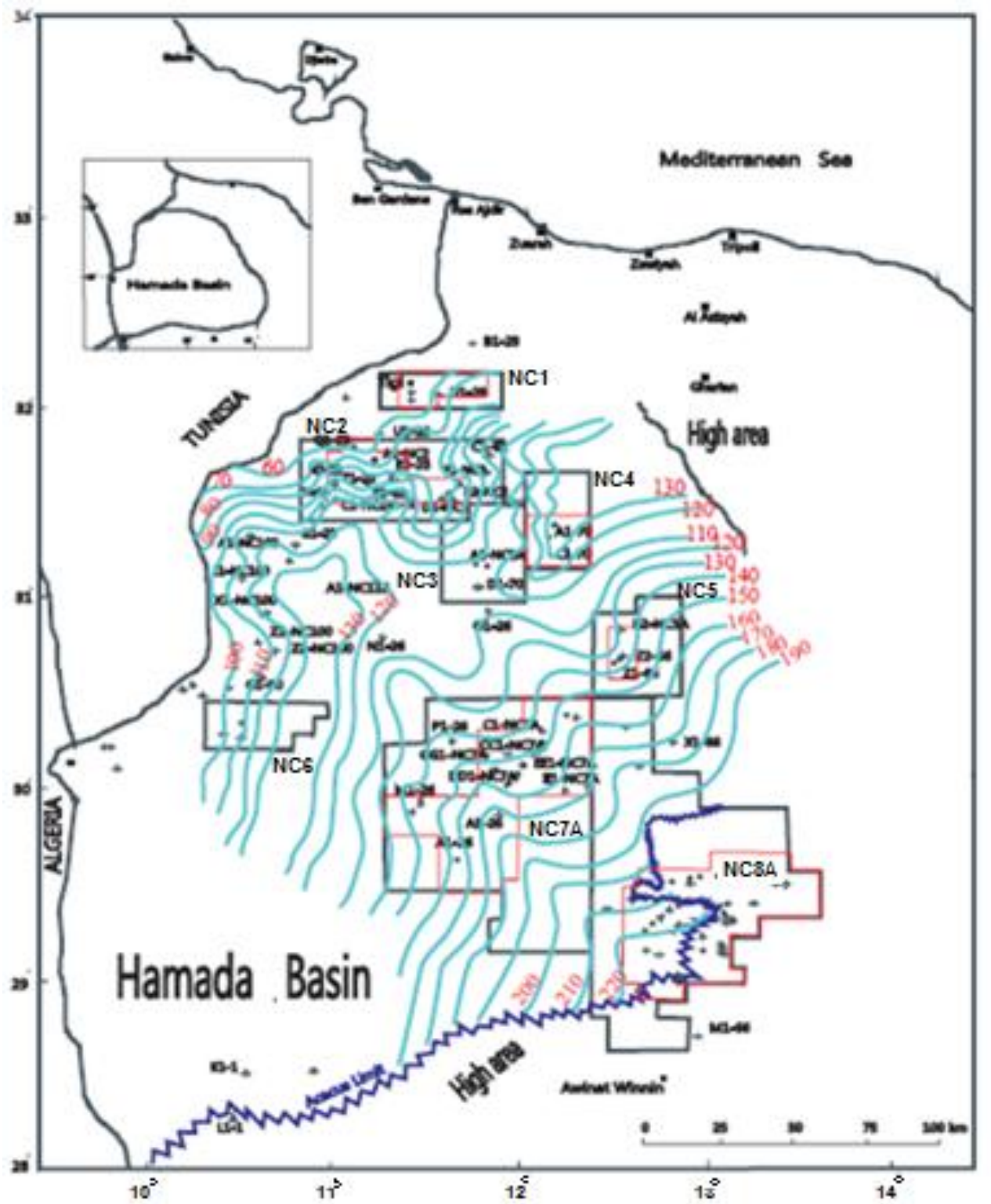

Figure11. Net sandstone isopach map of the Lower Acacus Formation, Ghadames Basin, NW Libya

\section{STRATIGRAPHIC INTEGRATION}

The integrated dataset including well logs, core description and thickness trend map is used to support the interpretation of possible two major deltaic complexes in the Lower Acacus sandstones (Fig. 12). These two deltaic complexes correspond to two distinct prograded clastic wedges (Figs.2 and 3), that appear to exhibit significant differences in thickness, extension and lithofacies development. The 
southern delta complex package is relatively of thicker sediments, river dominated and displaying evidence of south sediments source. The eastern deltaic complex is interpreted of thin sediments, storm-wave dominated, that has an eastern sourced area. This evolution of these two deltaic complexes consisting of several deltaic lobes or depocenters having major regional seaward/landward stepping, vertical stacking and flooding events that may cause shifting of depositional lobes.

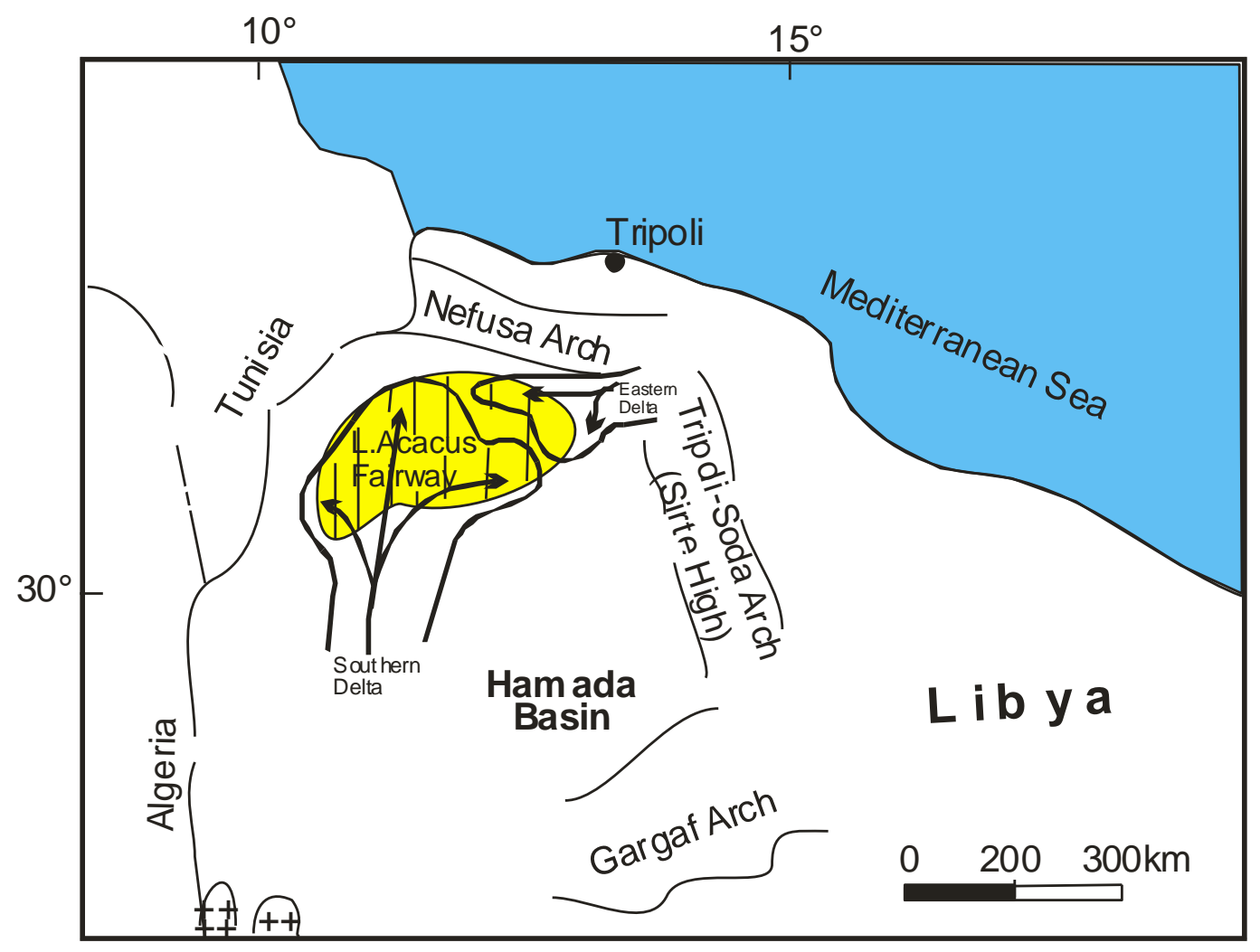

Figure12. Interpreted regional extent of the two possible deltaic complexes in the Lower Acacus Formation, Ghadames Basin, NW Libya.

\section{Determination of Lower Acacus Reservoir Play Fairway}

The integrated dataset (wireline logs, cores and maps) is used to study the regional lateral and vertical evolution of the sedimentary system and the structural framework to identify areas that have hydrocarbon potential. From the database, the play fairway is estimated to be about $200 \mathrm{~km}$ wide and $350 \mathrm{~km}$ long (grey shaded area), occupies a trend along the NW flank of the Ghadames Basin (Fig.13). To the east, the Lower Acacus sandstone terminates by Sirte high, which form the resistant eastern border of the Ghadames Basin. Southward, the fairway of the Lower Acacus was either eroded or terminated by series of orogenic events in the vicinity of Gargaf high. To the south of Gargaf high, the Lower Acacus sandstone outcrops almost continuously along the margin of Murzuk Basin, providing excellent exposure in Ghat area. Northward, the fairway margins are defined by increasing depth of burial, thinning and pinch out of the Lower Acacus sandstones to siltstone and shale beneath the Nefusa high. To date, drilling activities targeting these reservoir sandstones have been concentrated in the central (NC5, NC4, NC3 concessions), and northern part of fairway (NC2, NC1 concessions). The largest of these concessions is the NC2 which is have more than 20 wells. The Lower Acacus sandstone reservoirs in this concession average $25 \mathrm{ft}$ in thickness and occur at different depths as multiple pay zones (from 8000'to 9500'). Production from these sandstones in this NC2 concession has been impressive. Average daily flow rate have increased from less than 300BOPD and 0.1 MMCFGPD to more than 1000BOPD and 5 MMCFGPD. These positive flow rates typified most wells in the concession $\mathrm{NC} 2$ with decreases in water production.

Analyses of well test performance in the Ghadames (Hamada) Basin on the level of Lower Acacus sandstone reservoirs suggest an ultimate oil reserves in NC2 concession structures only are in range of 150-200 MMSTBOIP and 75-100 MMMSCFGIP. This translates into as much as 300-400 
MMSTBOIP and of about 150-200 MMMSCFGIP for the entire fairway in the Ghadames Basin. However, the most northern part of concession NC2 in the vicinity of wells A1-NC2, Q1-23 and U123, also concession $\mathrm{NC1}$ in the vicinity of well D1-23"Tigi area" are considered to be outside the interpreted play fairway of the Lower Acacus reservoirs (Fig. 13) as these wells are characterized by more low quality, silty-shaly sandstones of marginal part of the interpreted northward prograded delta.

$\mathrm{N}-\mathrm{S}$ structural cross section (Fig.14) is showing the structural style characterizing the Lower Acacus sandstone fairway. To the north and at the vicinity of NC2, NC3, NC4 and NC5 concessions, normal faulting, associated folding along with the development of good quality coastal-deltaic lobes are evident at Lower Acacus level. These faults appear to be associated with older basement rocks in the basin and are thus considered to be the effect of reactivation of older structures at Mesozoic or later age. in the vicinity of NC7A concession, fluvial channel sandstones of poor reservoir quality were dominating the area. Also, reverse faults are observed and display up to 100-150ft of vertical offset, they are generally strike parallel to the margins of the Silurian paleo-basins and may show some genetic relationship.

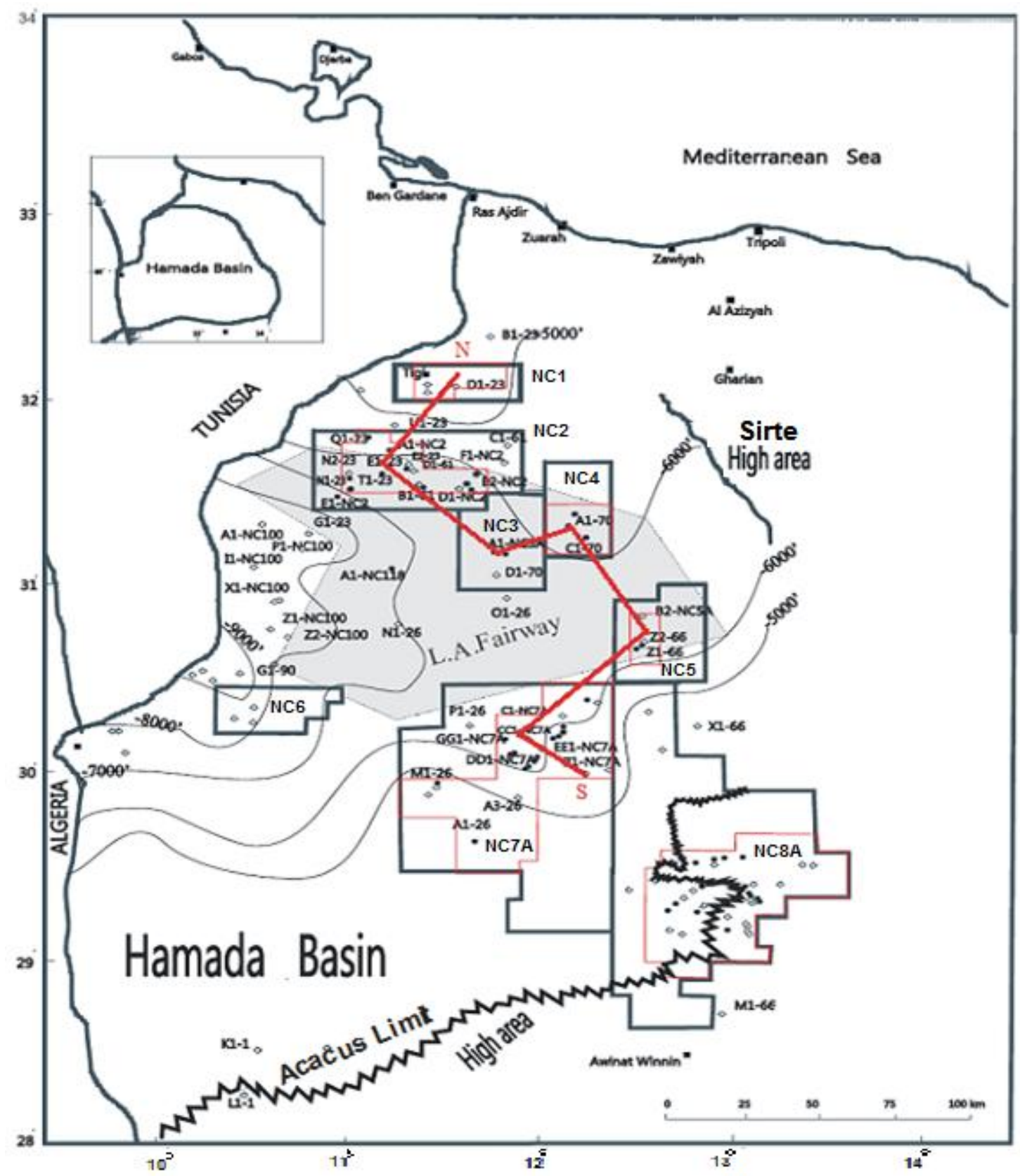

Figure13. Regional Structure Contour Map on Top of the Lower Acacus Formation, Ghadames, NW Libya. 


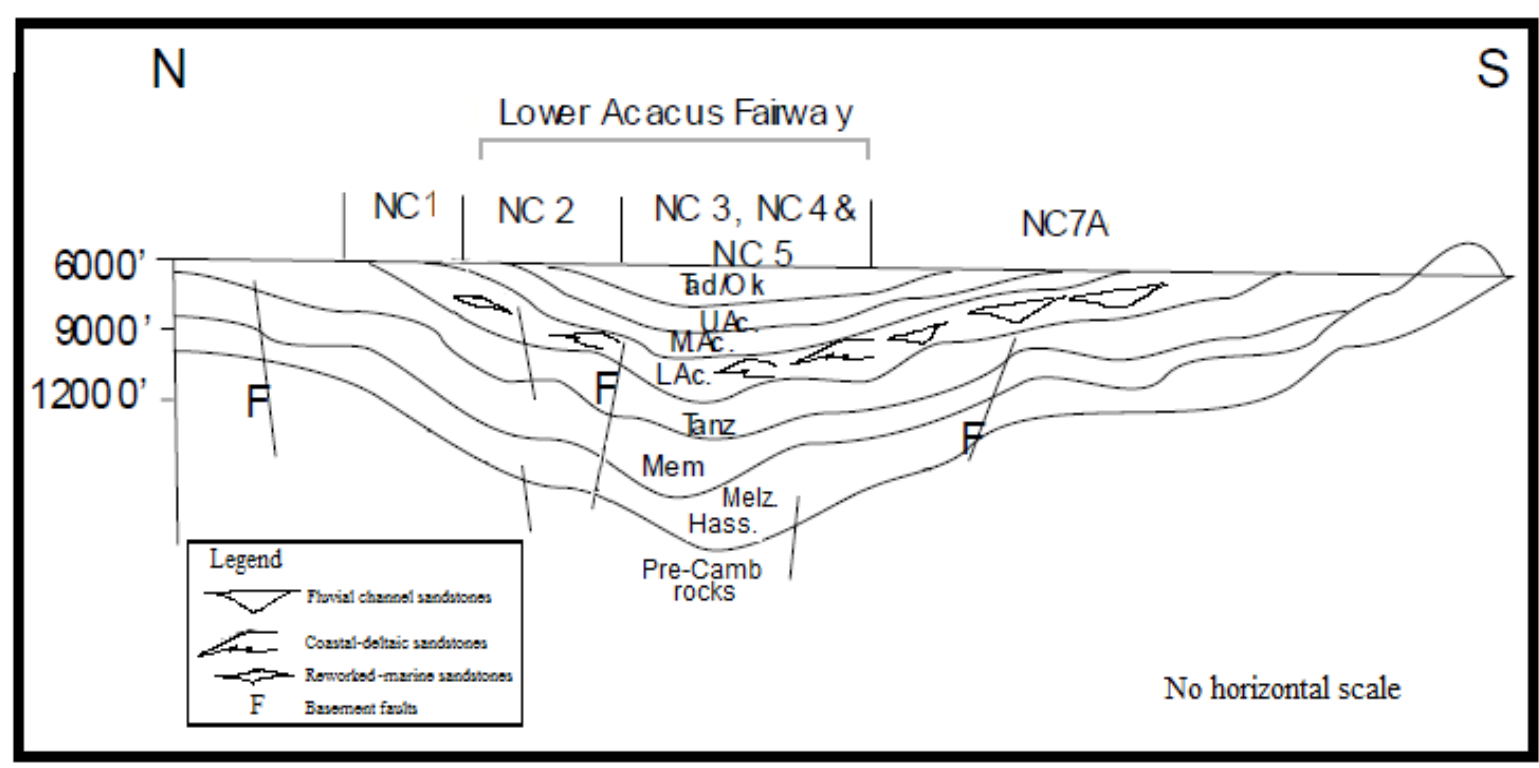

Figure14. North-South Cross Section Showing Structural Style of the Lower Acacus Fairway, Ghadames Basin, $N W$ Libya (see figure 13 to locate line of $N$-S cross-section).

\section{Conclusions}

The integrated dataset including well logs, core description and regional structural and net thickness trend maps is used to support the interpretation of possible two major deltaic complexes in the Lower Acacus sandstones. These two deltaic complexes correspond to two distinct prograded clastic wedges, that appear to exhibit significant differences in thickness, lateral extension and lithofacies development. The play fairway of the Lower Acacus reservoirs is typified most drilled wells in the concessions $\mathrm{NC} 2, \mathrm{NC} 3, \mathrm{NC} 4$ and $\mathrm{NC} 5$ in which good reservoir quality and sandstones distribution may serve to build play concepts for future prospect identification.

\section{ACKNOWLEDGEMENTS}

I am grateful to the Arabian Gulf Oil Company (AGOCO) for their generous help for providing me unlimited access to the core storage facility, and technical data library (TDL). I express my sincere thanks and appreciation to all who helped me in whatever capacity in preparing this paper.

\section{REFERENCES}

[1] Hammuda, O.S., 1980, Geologic factors controlling fluid trapping and anomalous freshwater occurrence in Tadrart sandstone, Al Hamada Al Hamra area, Ghadames Basin, in Salem, M., and Busrewil, M. (eds.), The Geology of Libya, Vol. II, p.501- 507.

[2] Echikh, A, and A.S. Suleiman, 1982, Preliminary geological study and petroleum evaluation of Ghadames Basin, NOC internal report.

[3] Shah, H.A., Elfigih O.B., and Shahlool A., 1988, Geological factors controlling the oil and gas deposits of Hamada Basin and recommendations for their future exploration, AGOCO internal report, Benghazi, 34p.

[4] Santa Maria, F.S., 1991, Ghadames Basin regional study, analysis and evaluation, AGOCO internal report, Benghazi, $158 \mathrm{p}$.

[5] Teknica Exploitation Group, Arabian Gulf Oil Company (AGOCO), 1995, Exploitation evaluation study in the west half of concession NC2, Benghazi, 95p.

[6] Elfigih, O.B., 1991, The sedimentology and reservoir characteristics of the Lower Acacus Formation, NC2 concession, Hamada Basin, NW Libya, MSc. thesis, Memorial University of Newfoundland, St.John's, Newfoundland, Canada, 569p.

[7] Cridland, R., 1991, Seismic stratigraphic evaluation of NC2 concession, Ghadames Basin, AGOCO, Benghazi, 78p. 
[8] Elfigih, O.B., 2000, Regional diagenesis and its relation to facies change in the Upper Silurian, Lower Acacus Formation, Hamada (Ghadames) Basin, northwestern Libya, Ph.D. thesis Memorial University of Newfoundland, St.John's, Newfoundland, Canada, 399p.

[9] Elfigih O. B., 2010, Regional aspects of the Lower Acacus sandstone play, Ghadames Basin, NW Libya, Fifth international conference on the geology of the Tethys Realm, South Valley University, Egypt, January 2010, P. 445-454.

[10] Elfigih O. B., 2010, The prospectivity of the Devonian reservoirs in the concession NC8A, Hamada (Ghadames) Basin, NW Libya (a case study), Fifth international conference on the geology of the Tethys Realm, South Valley University, Egypt, January 2010, p. 455-468.

\section{AUTHOR'S BIOGRAPHY}

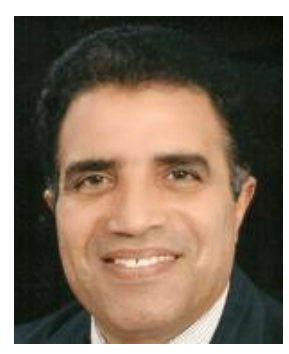

Dr. Omar B. Elfigih, is an associated professor and petroleum geologist at the Department of Earth Sciences, University of Benghazi. Born on Dec. 16.1959, he has an MSc and $\mathrm{PhD}$ in petroleum geology from Memorial University of Newfoundland-Canada. Worked for the Arabian Gulf Oil Company (AGOCO) as petroleum geologist, technical advisor and led the Ghadames Basin group for hydrocarbon exploration researches. He worked as private consultant and exploration geologist with BP-Libya. He was the head of the Department of Earth Sciences-University of Benghazi from Oct. 2014 to Oct. 2016. Head of scientific affairs at the University of Technical Research for Engineering Sciences (UTRES), Benghazi-Libya. Research interests involve sedimentary basin analysis for hydrocarbons exploration, reservoir characterization and evaluation and studies in petroleum system and stratigraphic models in exploration. He is a member in many geological societies; the Geological Association of Canada (GAC), the Earth Sciences Society of Libya (ESSL) and the American Association of Petroleum Geologists (AAPG). 